\title{
低速における超音速複葉翼の 3 次元空力性能評価*1 Evaluation of Three-Dimensional Low-Speed Aerodynamic Performance for a Supersonic Biplane
}

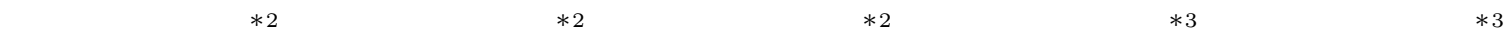 \\ Shuichi Ozaki, Toshihiro Ogawa, Shigeru Obayashi, Takashi Matsuno and Hiromitsu Kawazoe
}

Key Words : Supersonic Biplane, General Biplane Theory, Wake Survey, Induced Drag

\begin{abstract}
This study focuses on the aerodynamic performance of the supersonic biplane at the low-speed region. The performance was evaluated and discussed through Computational Fluid Dynamics (CFD) and Experimental Fluid Dynamics (EFD). The result of the CFD simulation was compared with the experimental result to validate the simulation and confirmed to be reliable. Therefore, the CFD results were employed to derive the aerodynamic performance coupled with the theoretical equations. In the wind tunnel experiment, the three-component force measurement was conducted to obtain lift, drag and pitching moment coefficients. The wake survey was conducted to measure the drag in detail. The results proved the low-speed aerodynamic performance of the supersonic biplane can be described by the classical "general biplane theory" reasonably well.
\end{abstract}

\section{1. は じめ に}

次世代の超音速旅客機開発の課題として , ソニックブー ムによる騒音や造波抗力による燃費効率の悪さがあげられ る. 現在, これらの課題を解決する手段として超音速複葉 翼理論 ${ }^{1)}$ を応用した機体コンセプトが提案されている.

超音速複葉翼理論とは, 第 1 図に示すように 2 枚の三角 形翼を互いに向き合わせることによって, 設計マッハ数で 衝撃波と膨張波が干渉し, 互いに相殺することでソニック ブームの騒音を大幅に低減できるというものである．また， 衝撃波を相殺することで, 体積に依存する造波抗力を低減 できる゙2).

超音速領域では衝撃波干渉といった有効な特性を示して いるが, 実際に超音速複葉翼を航空機の翼として利用する ためには, 非設計マッハ数領域の空力性能についても検証 を行わなければならない. 超音速旅客機コンコルドは巡航 時のソニックブームによる騒音問題だけでなく，低速時の空 力性能が低かったために, 離陸に際して高迎角かつアフター バーナを使用する必要があった . 従って, 超音速複葉翼に関 しても離着陸時の低速領域の空力性能を検証し向上させる 必要がある.こうした中で現在, 筆者らのグループでは数 值流体力学 (Computational Fluid Dynamics, CFD) と 実験流体力学 (Experimental Fluid Dynamics, EFD) の 両面から超音速複葉翼の低速空力性能の検証を行っている .

本研究では, 風洞実験の 3 分力計測により得られた超音 速複葉翼模型の空力性能と 3 次元 CFD 結果から , 複葉翼の

\footnotetext{
*1 (C) 2009 日本航空宇宙学会

平成 21 年 3 月 13 日原稿受理

*2 東北大学流体科学研究所

$* 3$ 鳥取大学工学部
}

古典理論を適用することで誘導抗力係数の算出を行う.ま た，算出した値を 2 次元 $\mathrm{CFD}$ 結果と後流計測によって算 出した誘導抗力係数と比較することで, 本研究で用いた算 出方法の妥当性を検証する.さらに，後流計測では 3 次元 翼の翼幅方向の抗力分布も明らかにできるため，本実験で 用いた後流計測手法を確立することで超音速複葉翼の抗力 メカニズムの解明を試みる .

\section{2. 数值計算手法}

2.1 流体解析ソルバ 本研究では流体の数值解析に非構 造 3 次元有限体積法コードである Tohoku university Aerodynamic Simulation code (TAS code) $)^{3,4)}$ を用いた . TAS code では Navier-Stokes 方程式をセル節点有限体積法によ り離散化し , 数值流束は Harten-Lax-van Leer-EinfeldtWada (HLLEW) 近似リーマン解法 ${ }^{5)}$ によって求めた . 時 間積分には計算時間を短縮するために非構造格子用に拡張 された LU-SGS 陰解法6) を用いた . 粘性流れにおける境界 層を精度よく解像するために物体表面に層状のプリズム格 子を形成している.乱流モデルはSST $k-\omega$ 乱流モデル 7$) を$ 用いて全面乱流として計算を行った .

本研究では低速領域の流れを対象としている．弚のため， 圧縮性 Navier-Stokes コードの適用範囲外であり，数值流 束の計算に用いられている上流型の差分は運動量方程式に対 して過乘な数値粘性を発生させることか指摘されている8) その対処法として, 本研究では計算上の音速を流れの速さ と同程度とする前処理法を用いた . 定式化はWeiss らの方 法9)に従い，LU-SGS に組み込んだものを用いた . 疑似音 速として用いる参照速度 $U_{\text {ref }}$ は, Weiss らの式の代わり に以下の式 (1) を採用した ${ }^{10)}$. 


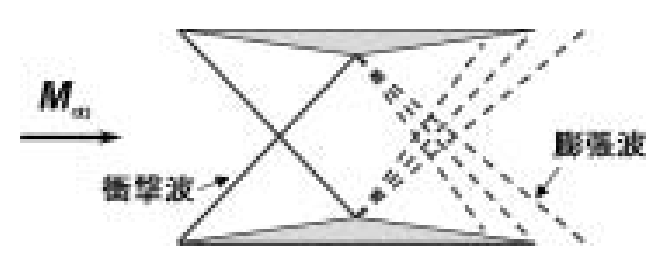

第 1 図 超音速複葉翼理論

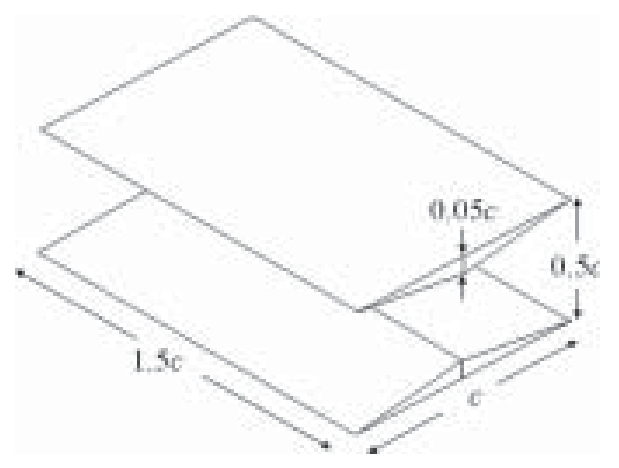

第 2 図計算対象形状

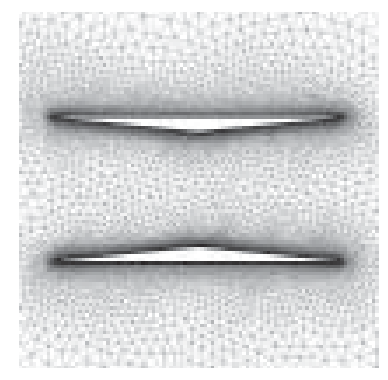

(a) 2 次元計算格子

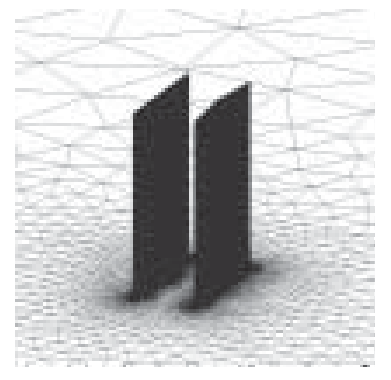

(b) 3 次元計算格子
第 3 図 計算格子

$$
U_{\text {ref }}=\min \left(a, \max \left(|u|, K U_{\infty}\right)\right)
$$

ここで $a$ は音速， $u$ は局所流速， $U_{\infty}$ は一樣流速度である． $K$ は定数で $K=0.5$ とした . 参照速度の最小值を局所音 速の $10^{-5}$ 倍程度とするWeiss らの式に比べて, $K U_{\infty}$ と することでよどみ点における計算の安定性を向上させる目 的がある .

計算条件は今回行った風洞実験と比較できるよう $U_{\infty}=$ $20[\mathrm{~m} / \mathrm{s}]$ と設定し，またレイノルズ数 $R e$ は風洞実験模型 の翼弦長 $c=100[\mathrm{~mm}]$ を代表長さにして $R e=1.73 \times 10^{5}$ とした . 迎え角 $\alpha$ は $\alpha=0 \sim 25[\mathrm{deg}]$ の範囲て解析した .

2.2 計算格子 本研究では, 非構造格子生成ツールであ るEdge Editor ${ }^{11)}$ を用いて計算格子を作製した .今回対象 とした翼型は, 線形理論をもとに巡航速度マッハ数 $M_{\infty}=$ 1.7 において衝撃波を相殺できるように設計された Busemann 複葉翼型 (基本形状) を用いた。第 2 図に基本形状 を翼型とした本数值計算て解析を行った形状を示す．また， 基本形状を翼型とした 2 次元計算格子およびアスペクト比 $A R=3$ の風洞実験模型を模擬した形状の 3 次元計算格子 を第 3 図に示す.

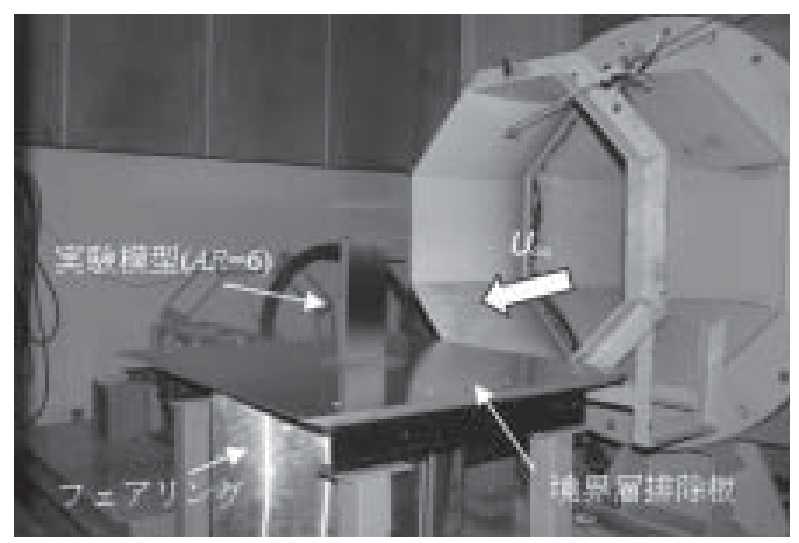

第 4 図風洞測定部

3. 風洞実験手法

3.1 風洞設備 本風洞実験は, 東北大学流体科学研究 所が所有する単路回流型の低乱熱伝達風洞を利用した . 本 設備では, 主流速度 $U_{\infty}=5 \sim 80[\mathrm{~m} / \mathrm{s}]$ までの計測が行え る . 測定部は開放型とし，正八角形断面となっている．ま た測定部の長さは $1.42 \mathrm{~m}$ である . 第 4 図に風洞の測定部 を示す．

$U_{\infty}$ の計測には，風洞の流入部に設置してある既設のピ ト一管を用いた .また，温度および大気圧に関しても既設 のメーターより随時取り込むことによって測定を行った・計 測機器への主流の影響を防ぐために，フェアリングを用い て主流か計測機器に直接当たらないようにした .さらに, 風 洞で発達した境界層の模型への影響を防ぐためにアルミ製 の境界層排除板を設置した .

3.2 風洞実験模型 本実験では $A R$ の異なる 2 種類の 模型を用いた . 模型の材質は加工か容易であり，湿気などに よる変形を最小限に抑えられる Carbon Fiber Reinforced Plastics (CFRP) を用いた。また，境界層排除板を対称面 とした半裁模型形態としたため, $A R$ の表記は模型サイズ 実寸の 2 倍とした .

第 1 表に模型の寸法を，第 5 図に実験で使用した超音速 複葉翼模型を示す．また, 実験模型の翼型としては, 設計 マッ八数 $M_{\infty}=1.7$ で衝撃波を相殺できる形状とした .

3.33 分力計測 3 分力天秤 (日章電機, LMC-3501$50 \mathrm{NS})$ を用いて， $U_{\infty}$ および $\alpha$ に対する実験模型の空気力 (揚力・抗力・ピッチングモーメントの 3 分力) を測定し , 揚 力係数 $C_{\mathrm{L}}$ および抗力係数 $C_{\mathrm{D}}$ を弚れ光れ求めた.$\alpha$ の変 更にはターンテーブル (シグマ光機, KSA-160PM) を用 い,ドライバ (オリエンタルモーター(株)，RKD514L-A)， モーションコントローラ (NATIONAL INSTRUMENTS ， UMI-7764）を用いてパルスを入力することで $\alpha$ の自動変 更を行った .

実験条件として, $U_{\infty}=20[\mathrm{~m} / \mathrm{s}], \alpha=0 \sim 30[\mathrm{deg}]$ の 範囲で風洞のレイノルズ数 $R e$ は, 実験模型の翼弦長 $c=$ $100[\mathrm{~mm}]$ を基準とした $R e=1.15 \times 10^{5}$ で計測を行った .

3.4 後流計測 本研究では 3 分力計測に加えて, 超音速 複葉翼の抗力メカニズムを解明するために後流計測を行っ 
第 1 表 実験模型寸法

\begin{tabular}{lcc}
\hline 実験模型 & $A R=3$ & $A R=6$ \\
\hline 翼弦長 $c[\mathrm{~mm}]$ & 100 & 100 \\
翼厚 $t[\mathrm{~mm}]$ & 5 & 5 \\
翼間距離 $g[\mathrm{~mm}]$ & 50 & 50 \\
翼幅 $b[\mathrm{~mm}]$ & 150 & 300 \\
\hline
\end{tabular}

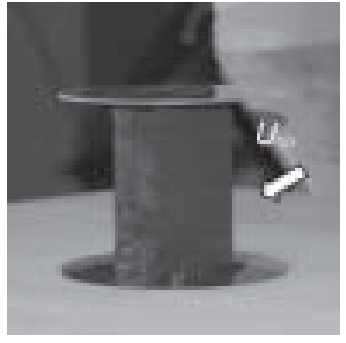

(a) $A R=3$

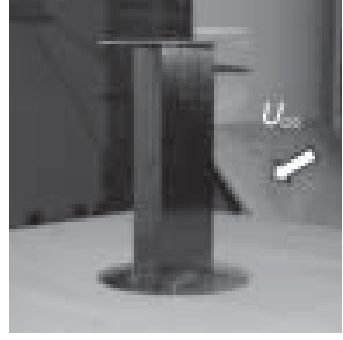

(b) $A R=6$
第 5 図風洞実験模型

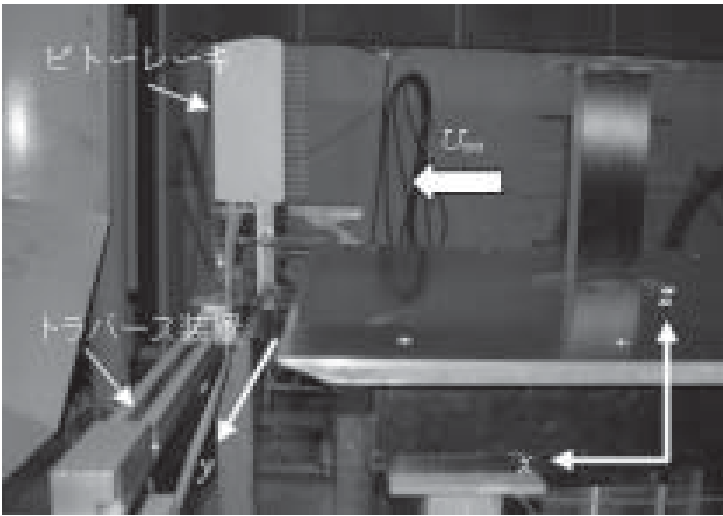

第 6 図 後流計測装置

た . 第 6 図に本実験で用いた後流計測装置を示す.ピトー レーキは 24 ポート装着しており，光れぞれのポート間は $10 \mathrm{~mm}$ 間隔である.なお，ピトーレーキに関しては，支持 部の調整により計測高さを変更できるようになっている．ま た，風洞内の主流総圧 $H_{0}$ および主流静圧 $p_{0}$ を測定する ために，ピト一管より静圧管と総圧管を分岐させて圧力セ ンサに取り込めるようにした .さらにトラバース装置によ り $y$ 方向にピトーレーキが $1 \mathrm{~mm}$ 間隔で移動し，後流総圧 $H_{2}$ を測定できるようにした . 第 7 図に後流総圧分布測定 の概要について示す .

第 7 図中の $p_{2}$ は後流静圧であり, 送風停止時にピトー レーキで測定した值を用いた.$W$ は後流圧力損失領域を 示している．また，本後流測定位置は模型の回転中心から 後方計測距離 $L_{x}=450[\mathrm{~mm}]$ とし, トラバース装置を用 いて $y$ 方向に模型中心の延長線を軸として $\pm 250 \mathrm{~mm}$ の 幅で計測を行った.$z$ 方向に関しては, 第 8 图で示したよ うにピトーレーキの最下部のポート番号 24 を境界層排除 板から $z=110[\mathrm{~mm}]$ の位置に, ポート番号 1 を翼端から $40 \mathrm{~mm}$ の位置 $(z=340[\mathrm{~mm}])$ に設置した .

実験条件として, $U_{\infty}=20[\mathrm{~m} / \mathrm{s}], \alpha=0,5,10[\mathrm{deg}]$

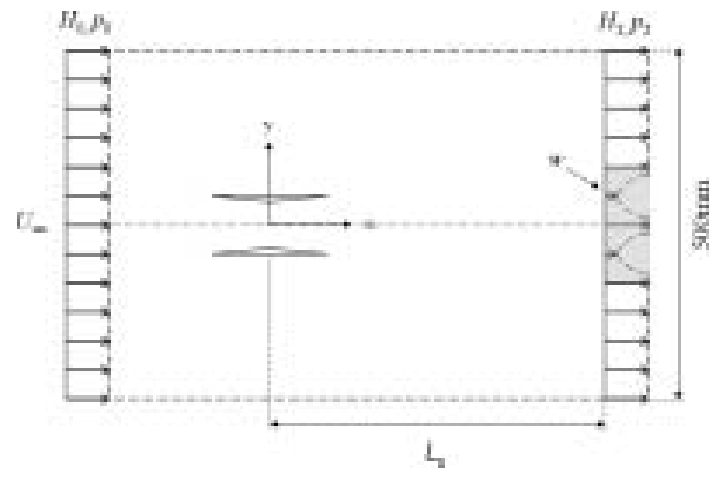

第 7 図 後流計測分布測定

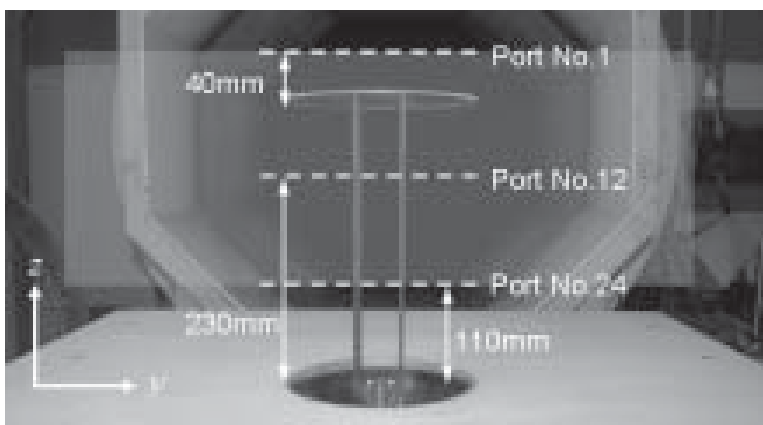

第 8 図 $z$ 方向の後流計測領域

で測定を行い，風洞のレイノルズ数 $R e$ は実験模型の翼弦 長 $c=100[\mathrm{~mm}]$ を基準とした $R e=1.15 \times 10^{5}$ で計測を 行った。

\section{3 分力計測と古典理論による空力性能解析}

4.1 空力性能比較 3 分力計測により $A R$ が異なる 2 種 類の模型の空力性能を計測した . 第 9 図に計測により得ら れた抗力極曲線を示す . また，比較対象として 3 次元 CFD 解析により得られた $A R=3$ 模型の空力性能についても 示す。

第 9 図より 3 分力計測により得られた $A R=3$ の空力性 能と CFD によって得られた空力性能が $C_{\mathrm{L}}=1.0$ 以下で は一致している.これは $C_{\mathrm{L}}$ が大きい領域では剝離領域が 大きくなり，本研究で行った定常計算では予測できなかっ たと考えられる.よって本解析では $C_{\mathrm{L}}=1.0$ 以下の空力 性能を中心に議論を行う .

4.2 複葉翼古典理論による誘導抗力算出 複葉翼の空 力性能を議論するうえで有効な手段として，1920 年代に Munk によって提案された複葉翼の古典理論 ${ }^{12)}$ がある .こ の理論は, 3 次元の翼理論 (Ludwig Prandtl, 1910's) を 複葉翼に応用した理論であり，風洞実験で取得した空力性 能データに適用させることで，より詳細な複葉翼の空力性 能を議論することができる．本研究では複葉翼古典理論を 超音速複葉翼に適用し, 3 分力計測結果を用いて誘導抗力 係数の算出を試みた .

式 (2) に複葉翼の全誘導抗力係数 $C_{\mathrm{D} i}$ の古典理論式を示 す.なお， $S$ は複葉翼の全面積であり，添え字 1 は上翼， 2 


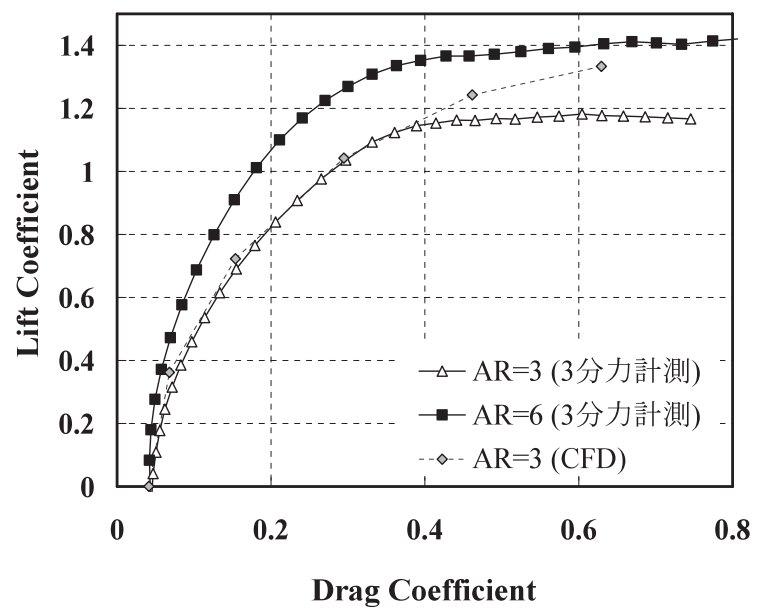

第 9 図 3 分力計測と 3 次元 CFD 解析による超音速複葉翼空力性能 比較

が下翼である .

$$
\begin{aligned}
& C_{\mathrm{D} i}=\frac{1}{\pi}\left(\frac{S}{b_{1}{ }^{2}} C_{\mathrm{L} 1}{ }^{2}+2 \sigma \frac{S}{b_{1} b_{2}} C_{\mathrm{L} 1} C_{\mathrm{L} 2}+\frac{S}{b_{2}{ }^{2}} C_{\mathrm{L} 2}{ }^{2}\right) \\
& \sigma \cong \frac{1-0.66 \mathrm{~g} / \mathrm{b}}{1.05+3.7 \mathrm{~g} / \mathrm{b}}
\end{aligned}
$$

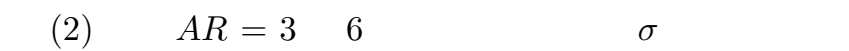
$\sigma=0.5340,0.6957$ となった . しかし, 本風洞実験で行った 3 分力計測では複葉翼のみの $C_{\mathrm{L}}$ しか計測していないため， 上翼，下翼での $C_{\mathrm{L}}$ は計測していない，弚のため, 式 (2) より $C_{\mathrm{D} i}$ を算出することはできない，光こで， $C_{\mathrm{L} 1}$ および $C_{\mathrm{L} 2}$ が未知の場合でも，上下翼の揚力比 $\nu\left(=C_{\mathrm{L} 2} / C_{\mathrm{L} 1}\right)$ から $C_{\mathrm{D} i}$ を算出する手法を検討した .

まず，算出に用いる上翼，下翼の揚力割合の関係式を式 (3) , (4) に示す . なお , 複葉翼の上下翼の翼幅比 $\mu$ を $\mu=$ $b_{2} / b_{1}$ とする .ただし , 本関係式は $C_{\mathrm{D} i}$ が最小と仮定した 場合，つまり，本来は楕円翼にのみ適用可能であるが本風 洞実験模型の矩形翼にも適用した .

$$
\begin{aligned}
& \nu=\frac{\mu-\sigma}{(1 / \mu)-\sigma} \\
& C_{\mathrm{L} 1}=C_{\mathrm{L}} /(1+\nu), \quad C_{\mathrm{L} 2}=\nu C_{\mathrm{L}} /(1+\nu)
\end{aligned}
$$

式 (3) を用いると, 本研究で対象とした超音速複葉翼で は上翼と下翼の翼幅が同じであるため $\nu=1$ となり，式 (4) より $C_{\mathrm{L}}$ が上翼と下翼で同じになると推定されることがわ かった . しかし, 今回の翼型は上下対称な翼型ではあるが， キャンバーが逆対称な形状であるため上下翼の $C_{\mathrm{L}}$ が同じ になるとは考えにくい，乥こで，第 2 表に示す 3 次元 CFD 解析 $(A R=3)$ により得られた上翼と下翼の $\nu$ をいた . なお， $\alpha=0[\mathrm{deg}]$ では上翼と下翼が上下対称翼となり揚力 は発生しないため，理論值である $\nu=-1$ とした . また， $\alpha=5$ [deg] における上翼では逆キャンバー翼であるために， 3 次元 $\mathrm{CFD}$ 結果では $C_{\mathrm{L}}$ がほぼゼロとなるため除外する こととした .
第 2 表 3 次元 $\mathrm{CFD}$ 解析により得られた複葉翼揚力比 $(A R=3$ 模型 $)$

\begin{tabular}{cc}
\hline$\alpha[\mathrm{deg}]$ & $\nu$ \\
\hline 0 & -1 \\
5 & - \\
10 & 2.4820 \\
15 & 2.2177 \\
20 & 2.5109 \\
平均値 $(10 \sim 20)$ & 2.4040 \\
\hline
\end{tabular}

第 3 表 古典理論による誘導抗力算出に用いた係数

\begin{tabular}{cll}
\hline 実験模型 & $A R=3$ & $A R=6$ \\
\hline$g / b$ & 0.1667 & 0.8333 \\
$\sigma$ & 0.5340 & 0.6957 \\
$\nu$ & 2.4040 & 2.4040 \\
$\mu$ & 1 & 1 \\
$k$ & 1.1134 & 1.0698 \\
\hline
\end{tabular}

第 2 表より $C_{\mathrm{D} i}$ 算出において $\nu$ は定義できたことから， 式 (3)，(4) を用いて式 $(2) の C_{\mathrm{L} 1} ， C_{\mathrm{L} 2}$ を消去し， $\nu$ を含 めた式に変換すると式 (5) が得られる.

$$
C_{\mathrm{D} i}=\frac{S C_{\mathrm{L}}^{2}}{2 \pi b_{1}^{2}} \frac{\mu^{2}+2 \mu \nu \sigma+\nu^{2}}{\mu^{2}(1+\nu)^{2}}
$$

また，式 (6)で $k$ (Munk's span factor) を定義し，式 (5) に代入すると式 $(7)$ か得られる .ここで, $k$ は複葉翼の 前面から見た形状，つまり，翼幅 $b$ と翼間距離 $g$ によって 変化する值である。

$$
\begin{gathered}
k=\frac{(1+\nu) \mu}{\sqrt{\mu^{2}+2 \mu \nu \sigma+\nu^{2}}} \\
C_{\mathrm{D} i}=\frac{S C_{\mathrm{L}}{ }^{2}}{\pi\left(k b_{1}\right)^{2}}=\frac{C_{\mathrm{L}}{ }^{2}}{\pi k^{2} A R}
\end{gathered}
$$

式 $(7)$ より $k$ が既知であれば $C_{\mathrm{D} i}$ が算出できることが わかる. 式 (6) を用いて第 2 表の $\alpha=10 \sim 20$ [deg] の平均 值 $\nu=2.404$ より $A R=3$ および 6 の実験模型について $k$ を算出すると弚れ光れ， $k=1.1134,1.0698$ となる.これ は , 一般的な複葉翼の $k=1.1000 \sim 1.140(A R=3)$ お よび $k=1.0400 \sim 1.0900(A R=6)^{12)}$ の範囲内であるか ら，ここで得られた值は妥当である。以上，これまでの算 出過程で求めた係数を整理すると第 3 表のようになる.

次に, 本手法を用いて 3 分力計測結果より誘導抗力係数 の算出した結果を第 10 図に示す.第 10 図より同じ $C_{\mathrm{L}}$ 下 において $A R=3$ 模型の $C_{\mathrm{D} i}$ が $A R=6$ 模型の $C_{\mathrm{D} i}$ に 対してほぼ 2 倍となることが確認できる.これは一般的な 単葉翼に見られる傾向と一致している。しかし, 複葉翼の 場合は $C_{\mathrm{D} i}$ を算出する際に $k$ の要素か加わるため, 厳密 には 2 倍となっていない .ここで, 算出した $C_{\mathrm{D} i}$ の妥当性 について,$A R=3$ および $A R=6$ の実験模型の $C_{\mathrm{D} i}$ を 式 (8)により評価することで検証した .

$$
C_{\mathrm{d}, \mathrm{EFD}}=C_{\mathrm{D}}-C_{\mathrm{D} i}
$$

式 (8) は, 3 分力計測で得られた模型の全抗力係数 $C_{\mathrm{D}}$ か 


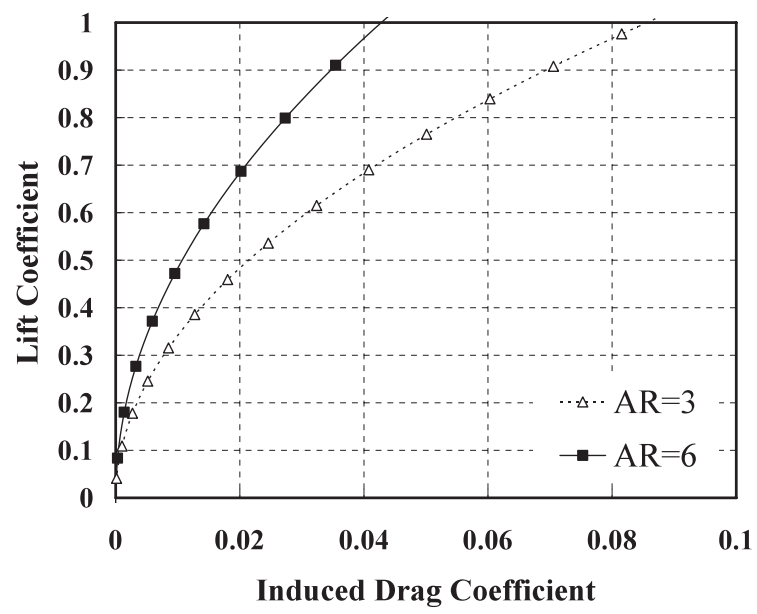

第 10 図 古典理論より算出したアスペクト比の違いによる誘導抗力 係数

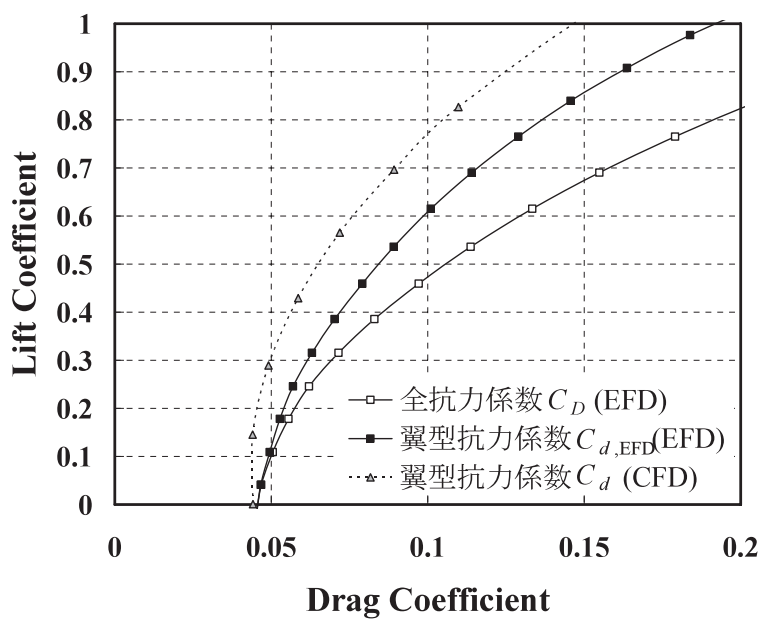

(a) $A R=3$

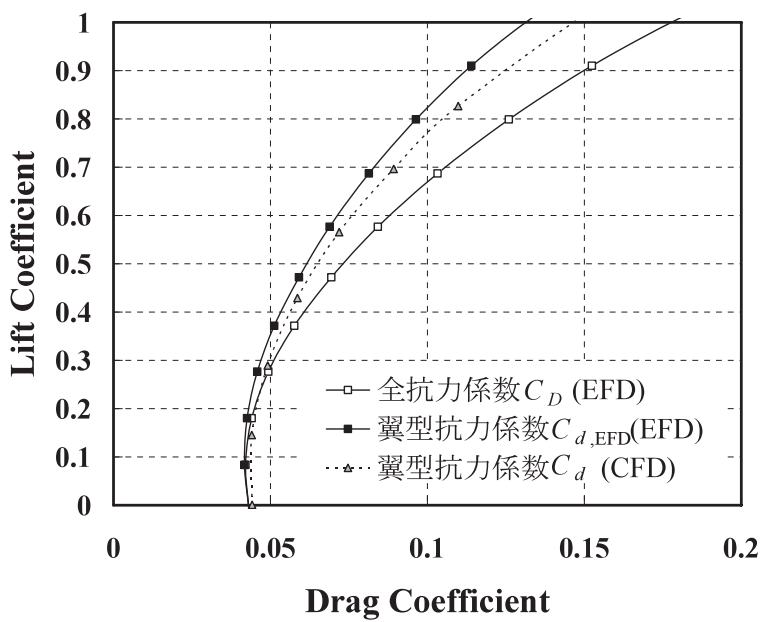

(b) $A R=6$

第 11 図 3 分力計測と CFD の翼型抗力係数比較

ら，算出した $C_{\mathrm{D} i}$ を引いた值を実験模型から算出した 2 次元抗力係数 $C_{\mathrm{d}, \mathrm{EFD}}$ (翼型抗力係数) として定義したも のである.第 11 図 (a)に $A R=3$ 模型について算出した $C_{\mathrm{d}, \mathrm{EFD}}$ と 2 次元 CFD 解析により得られた $C_{\mathrm{d}}$ の比較を
示す.なお， 3 分力計測より得られた $A R=3$ 実験模型の $C_{\mathrm{D}}$ も比較対象として示す.

第 11 図 (a) より $C_{\mathrm{d}, \mathrm{EFD}}$ と $C_{\mathrm{d}}$ が一致しないことが確 認できる .この理由としては，本実験では境界層排除板を 対称面とした半裁模型形状としているために，3 分力計測 結果には境界層排除板上で発達した境界層による影響や対 称面に物体があることによる流れ場への影響などが考えら れる.これらの影響か実際の $A R=3$ の翼での抗力を増大 させ , 有害抗力となって 3 分力計測結果に加わっているこ とが原因だと考えられる．つまり，3 分力計測結果の抗力 内訳を式 (9) に示すと，

$$
C_{\mathrm{D}}=C_{\mathrm{d}}+C_{\mathrm{D} i}+C_{\mathrm{Dp}}
$$

となり, 有害抗力係数 $C_{\mathrm{Dp}}$ の増加分だけ $C_{\mathrm{d}, \mathrm{EFD}}$ が $C_{\mathrm{d}}$ と一致していないと考えられる .

$A R=6$ 模型についても同樣に式 (8) より算出した $C_{\mathrm{d}, \mathrm{EFD}}$ と 2 次元 CFD 解析により得られた $C_{\mathrm{d}}$ とを比較し た結果を第 11 図 (b) に示す.第 11 图 (b)より， $C_{\mathrm{d}, \mathrm{EFD}}$ と $C_{\mathrm{d}}$ が $A R=3$ 模型のときに比べ近い值を示している .この 理由としては, $A R=6$ 模型では $A R=3$ 模型に比べて翼 幅が大きくなるため $C_{\mathrm{Dp}}$ が小さくなり, 兴の分 $C_{\mathrm{d}, \mathrm{EFD}}$ が $C_{\mathrm{d}}$ に近い值を示したと考えられる.しかし一方で， $A R=$ 6 模型では $A R=3$ 模型とは異なり $C_{\mathrm{d}, \mathrm{EFD}}$ が $C_{\mathrm{d}}$ より も小さな値を示している.これは, 本手法では $A R=3$ 模 型の 3 次元 CFD 解析により得られた揚力比 $\nu$ の平均值を 用いて $C_{\mathrm{D} i}$ を算出しており，実際の $A R=6$ 模型の $\nu$ と は異なっている可能性がある.よって $A R=6$ 模型の $C_{\mathrm{D} i}$ が大きく見積もられており， $C_{\mathrm{d}, \mathrm{EFD}}$ が $C_{\mathrm{d}}$ よりも小さい 値を示していると考えられる，乥こで，本手法の妥当性を 検証するために後流計測による $C_{\mathrm{D} i}$ 算出を試みた .

\section{5. 後流計測による抗力解析}

翼端付近の後流計測により，風洞実験模型の誘導抗力係 数 $C_{\mathrm{D} i}$ の算出を試みた . 本解析は 3 分力計測結果より複 葉翼古典理論を用いて算出した $C_{\mathrm{D} i}$ と比較することで, 両 者の精度検証を行うとともに, 翼幅方向の抗力分布の解明 も試みた。

まず, 本計測で得られた計測面での正規化動圧 $P_{\text {norm }}$ 分 布を第 12 図に示す．なお，正規化には式 (10) を用いた .

$$
P_{\text {norm }}=\frac{H_{2}-p_{2}}{H_{0}-p_{0}}
$$

第 12 図より翼端渦を捉えているのか確認できる. 第 12 図 (a) より超音速複葉翼の場合， $\alpha=0[\mathrm{deg}]$ でも翼端渦が発 生しており，これにより $C_{\mathrm{L}}=0$ でも誘導抗力が生じてい ることがわかる.第 12 図 (b) では, 両翼の翼端渦とも翼面 上方向に生じており，下翼の翼端渦の方が大きくなっている のがわかる .これは上翼に比べ下翼の方が揚力を発生して おり，上翼ではほとんど揚力を発生していないためである。 第 12 図 (c)では, 上翼の翼端渦が翼幅方向の内側まて影響

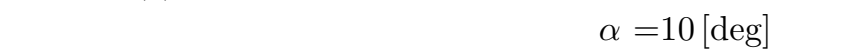




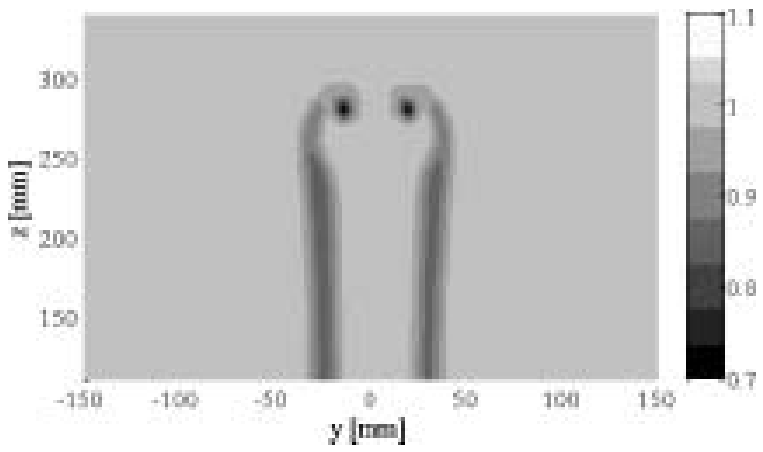

(a) $\alpha=0[\mathrm{deg}]$

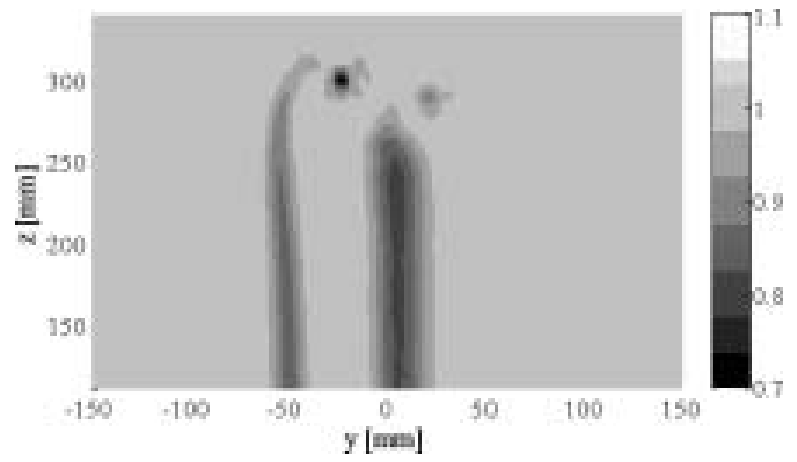

(b) $\alpha=5[\mathrm{deg}]$

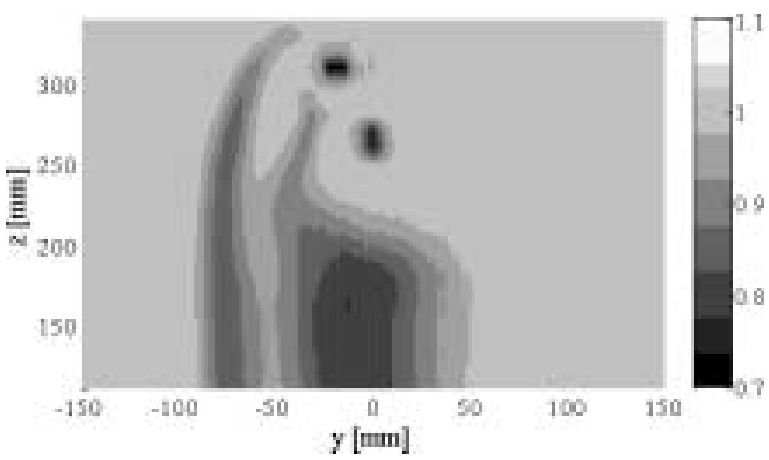

(c) $\alpha=10[\operatorname{deg}]$

第 12 図翼端付近の正規化動圧分布 (左が下翼, 右が上翼)

$C_{\mathrm{L}}$ が大きくなり, 翼端渦の影響が強くなるためである .

次に, 翼断面における翼型抗力係数 $C_{\mathrm{d}}$ (2 次元抗力係数) を求めることで翼幅方向の抗力分布の解析を行った . 本解 析では Jones により提案された $C_{\mathrm{d}}$ 算出式13)をもとに，第 2 項の分母を $p_{0}$ ではなく $p_{2}$ とした公式14) を用いた. 式 (11) に本研究で用いた $C_{\mathrm{d}}$ 算出式を示す.なお, 式中の係 数については第 7 図に示してある.

$$
C_{\mathrm{d}}=\frac{2}{c} \int^{W} \frac{\sqrt{H_{2}-p_{2}}}{\sqrt{H_{0}-p_{0}}}\left(1-\frac{\sqrt{H_{2}-p_{2}}}{\sqrt{H_{0}-p_{0}}}\right) \mathrm{d} y
$$

ここで式 (11) 中の $W$ は後流圧力損失領域であり， $\alpha$ に応 じて $W$ も変化するため適宜 $W$ を変更して Jones の式に 対応させた . 式 (11) を用いて算出した計測断面における翼 幅方向の翼型抗力係数分布を第 13 図に示す.第 13 図より， $\alpha=0,5[\mathrm{deg}]$ では翼端以外の領域では $C_{\mathrm{d}}$ 分布が一樣に なっているのか確認できる . 一方で $\alpha=10[\mathrm{deg}]$ では $z=$

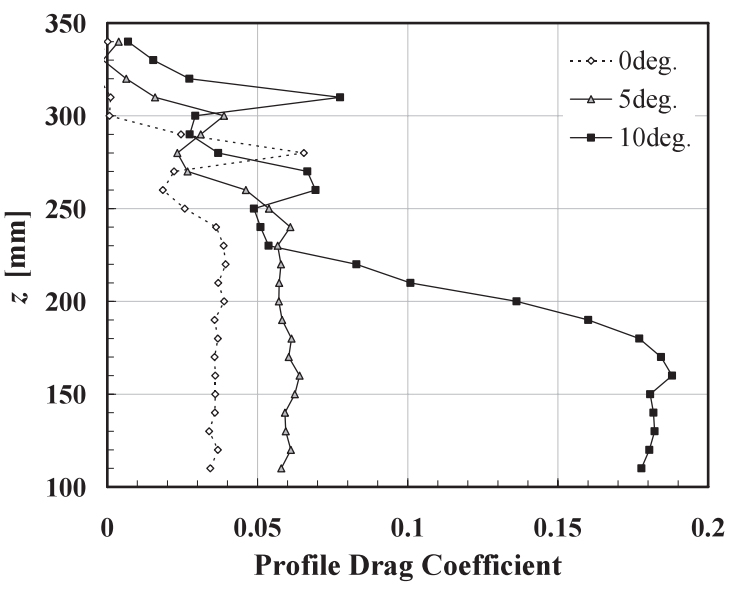

第 13 図 翼幅方向の翼型抗力係数分布

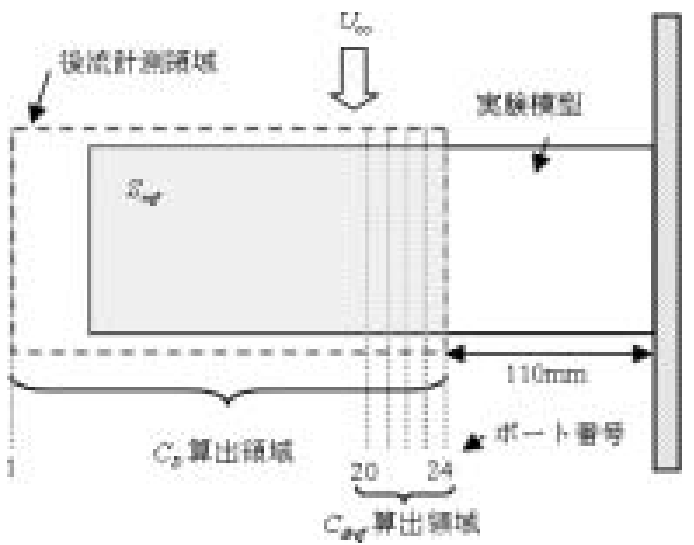

第 14 図 後流計測による誘導抗力算出手法

150 以下でようやく一樣になっている .これは翼端渦が翼 中央部まで影響しているためである .

続いて，第 13 図で示した $C_{\mathrm{d}}$ をもとに算出した $C_{\mathrm{D} i}$ に ついて説明する.第 14 図に誘導抗力算出手法についての 概要図を示す.

第 14 図より， $S_{\mathrm{ref}}$ はピトーレーキが捉えている実験模 型の領域内の複葉翼の面積としており, 本計測では $S_{\mathrm{ref}}=$ $0.019\left[\mathrm{~m}^{2}\right]$ となる . 式 $(12)$ に翼端領域の全抗力係数 $C_{\mathrm{D}}$ を 求める式を示す.

$$
C_{\mathrm{D}}=\frac{2}{S} \iint_{W} \frac{\sqrt{H_{2}-p_{2}}}{\sqrt{H_{0}-p_{0}}}\left(1-\frac{\sqrt{H_{2}-p_{2}}}{\sqrt{H_{0}-p_{0}}}\right) \mathrm{d} y \mathrm{~d} z
$$

$C_{\mathrm{D}}$ に関してはピトーレーキで計測した全領域を対象とした 值を算出している.これは, 翼端以外の領域 $(z=300[\mathrm{~mm}]$ 以上の領域) でも翼端渦の影響が生じているためであり，こ の領域も捉えられるようにしているためである .ここで， $C_{\mathrm{D}}$ を用いて $C_{\mathrm{D} i}$ を算出する式を式 $(13)$ に示す.

$$
C_{\mathrm{D} i}=C_{\mathrm{D}}-C_{\mathrm{dref}}
$$

式 (13) 中の $C_{\text {dref }}$ は, 計測領域内において $z=110 \sim 150$ の $C_{\mathrm{d}}$ を平均した值を用いた .この理由としては, 第 13 図の翼型抗力係数分布より $z=100 \sim 150$ の領域について 
第 4 表 後流計測より算出した係数

\begin{tabular}{lccc}
\hline$\alpha[\mathrm{deg}]$ & 0 & 5 & 10 \\
\hline$C_{\mathrm{D}}$ & 0.0356 & 0.0689 & 0.2180 \\
$C_{\mathrm{dref}}$ & 0.0354 & 0.0600 & 0.1816 \\
$C_{\mathrm{D} i}$ & 0.0002 & 0.0089 & 0.0364 \\
\hline
\end{tabular}

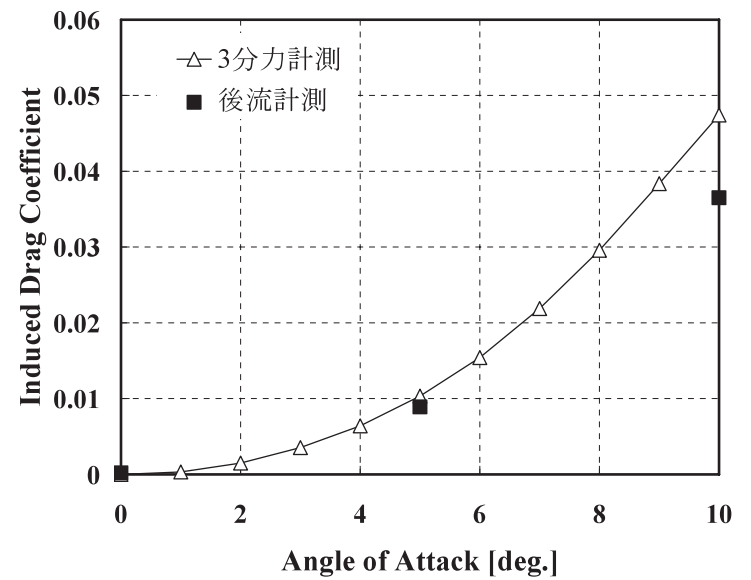

第 15 図 誘導抗力係数比較

は， $C_{\mathrm{d}}$ の值がほぼ一定となっているため，この領域の值 を $C_{\mathrm{dref}}$ とした .式 (12)，(13) を用いて後流から算出した $\alpha=0,5,10[\mathrm{deg}]$ における $C_{\mathrm{D}}, C_{\mathrm{dref}}, C_{\mathrm{D} i}$ を第 4 表に 示す.また，第 4 表で示した $C_{\mathrm{D} i}$ を, 3 分力計測結果から 複葉翼古典理論を用いて算出した $A R=6$ 実験模型の $C_{\mathrm{D} i}$ と比較すると第 15 図のようになる .

第 15 図より，3 分力計測結果から古典理論を用いて算 出した $C_{\mathrm{D} i}$ と後流計測結果から算出した $C_{\mathrm{D} i}$ は $\alpha=0$, $5[\mathrm{deg}]$ ではよく一致している.一方で， $\alpha=10$ [deg] では 後流計測結果から算出した $C_{\mathrm{D} i}$ の方が小さく見積もられ ている.これは本手法で参照した $C_{\mathrm{dref}}$ は，第 13 図より $C_{\mathrm{d}}$ 分布が翼幅方向に一定になっていると仮定した領域の 值であるが， $C_{\mathrm{L}}$ が大きい $\alpha=10[\mathrm{deg}]$ では翼端渦の影響 か強いため $z$ が 100 より小さい領域においても $C_{\mathrm{d}}$ 分布が 変化していると考えられ, 参照した $C_{\mathrm{dref}}$ か実際の翼型抗 力係数よりも大きな值を参照したことが 1 つの要因として 考えられる.よって, 本計測で用いたピトーレーキでは翼

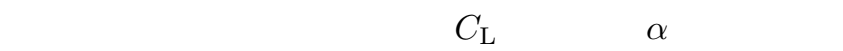
は $z=100[\mathrm{~mm}]$ 以下の翼中央部の領域を含めた翼全体を 網羅した計測を行う必要がある.また別の理由として，古 典理論より算出した $C_{\mathrm{D} i}$ が大きく見積もられている可能 性がある．このことは 4.2 節で述べたとおりである．しか し，僅かな差はあるが $\alpha=0,5[\mathrm{deg}]$ て理論式から算出し た值とほぼ一致したことを考慮すると，本手法により $C_{\mathrm{D} i}$ 算出は可能であることが示せたといえる．また同時に，後 流計測により超音速複葉翼の翼幅方向の $C_{\mathrm{d}}$ 分布の解析も 可能になったといえる .
6. 結 論

本研究では, CFD, EFD で得られた結果に加えて, 複 葉翼の古典理論による議論を交えることで超音速複葉翼の 低速空力性能について解析を行った . 兴の結果 , 後流計測 では翼幅方向の抗力分布が明らかになり，翼端渦を捉える ことができた . また , 3 分力計測で取得したデータに対して 複葉翼の古典理論を適用することで算出した誘導抗力係数 と後流計測により算出した誘導抗力係数が $\alpha=0,5[\mathrm{deg}]$ の場合は一致した .

本研究により, CFD および EFD, 複葉翼の古典理論を 組み合わせた議論を行うことで超音速複葉翼の低速空力性 能を明らかにすることができ, 超音速複葉機の抗力低減に 向けた抗力メカニズムの解明手段として , 本実験で用いた 後流計測手法の有効性が示せたといえる .

参 考 文 献

1) Kusunose, K., Matsushima, M., Obayashi, S., Furukawa, T., Kuratani, N., Goto, Y., Maruyama, D., Yamashita, H. and Yonezawa, M.: Aerodynamic Design of Supersonic Biplane: Cutting Edge and Related Topics, The 21st Century COE Program International COE of Flow Dynamics Lecture Series, Vol. 5, Tohoku Univ. Press, Sendai, 2007.

2) Liepmann, H. W. and Roshko, A.: Elements of Gas Dynamics, John Wiley \& Sons, New York, 1957, pp. 107-123.

3) Ito, Y. and Nakahashi, K.: Direct Surface Triangulation Using Stereolithography Data, AIAA J., 40 (2002), pp. 490496.

4) Ito, Y. and Nakahashi, K.: Surface Triangulation for Polygonal Models Based on CAD Data, Int. J. Numer. Meth. Fluids, 39 (2002), pp. $75-99$.

5) Obayashi, S. and Guruswamy, G. P.: Convergence Acceleration of an Aeroelastic Navier-Stokes Solver for Efficient Static Aeroelastic Computations, AIAA J., 33 (1995), pp. 1134-1141.

6) Sharov, D. and Nakahashi, K.: Recording of Hybrid Unstructured Grids for Lower-Upper Symmetric Gauss-Seidel Computations, AIAA J., 36 (1998), pp. 484-486.

7) Menter, F. R.: Two-Equation Eddy-Viscosity Turbulence Models for Engineering Applications, AIAA J., 32 (1994), pp. 269-289.

8) 向井純一: 低速流れの非定常計算における人工粘性の影響, 航空 宇宙数值シミュレーションシンポジウム 2005 概要集, $2005, \mathrm{p}$. 30.

9) Weiss, M. J. and Smith, W. A.: Preconditioning Applied to Variable and Constant Density Flows, AIAA J., 33 (1995), pp. 2050-2057.

10) Luos, H., Baum, J. D. and Löhner, R.: Extension of HartenLax-van Leer Scheme for Flows at All Speeds, AIAA J., 43 (2005), pp. 1160-1166.

11) Ito, Y. and Nakahashi, K.: Improvements in the Reliability and Quality of Unstructured Hybrid Mesh Generation, Int. J. Numer. Meth. Fluids, 45 (2004), pp. 79-108.

12) Munk, M. M.: General Biplane Theory, Technical Report, No. 151, N.A.C.A., Washington D.C., 1923.

13) Goett, H. J.: Experimental Investigation of the Momentum Method for Determining Profile Drag, Technical Report, No. 660, N.A.C.A., Washington D.C., 1939.

14) 谷一郎, 小橋安次郎, 佐藤 浩: 流体力学実験法, 岩波書店, 東京, 1977, pp. 225-226. 